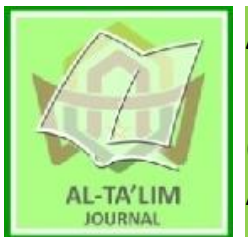

AL-TA'LIM JOURNAL, 27 (2), 2020, (140-155)

(Print ISSN 1410-7546 Online ISSN 2355-7893)

Available online at http://journal.tarbiyahiainib.ac.id/index.php/attalim

\title{
The Effectiveness of Islamic Education Learning with Creative Worksheets through the Application of Quipper with Facebook Account
}

Received: $28^{\text {th }}$ March 2020; Revised: $07^{\text {th }}$ July2020; Accepted: $30^{\text {th }}$ July 2020

Permalink/DOI: http://dx.doi.org/10.15548/it.v27i2.619

\section{Wardah Hanafie Das *)}

Universitas Muhammadiyah Parepare, Indonesia.

E-mail:wardahhadas@gmail.com

\section{Abdul Halik \\ Institut Agama Islam Negeri Parepare \\ E-mail: abdulhaliknas@gmail.com}

\section{Besse Tuti Herlin \\ Universitas Muhammadiyah Parepare, Indonesia. \\ E-mail: bessetuti_herlina@gmail.com}

\section{*) Corresponding Author}

\begin{abstract}
This study aims to determine the significance differences by those who are taught using Quipper through a facebook account in assigning creative worksheets and those who are not taught using Quipper in the field of Islamic education studies. This research method is an experiment with Quasi Nonequivalent control group design. The population was 70 people and the sample was divided into experiment class and control class with a total of 35 people each. The research instrument was the Observation Sheet, Student Learning Outcomes Test in the form of worksheets, questionnaires, study documents, and triangulation. Quantitative data analysis with descriptive and inferential non-parametric statistical techniques Mann Whitney U-Test test. Data analysis was assisted by SPSS application version 24. The results of the study were the use of Quipper School through a Facebook account in assigning creative worksheets to improve the effectiveness of Islamic education learning in SMK Negeri 1 Sengkang meeting the KKM, and there were significant differences between use and not use Quipper School through facebook account in assigning creative worksheets, and in the mann-whitney test, it is known the value of Asymp. Sig. (2- tailed) of 0,000 is smaller than <probability value of 0.05 then the hypothesis $\mathrm{H}_{0}$ is rejected $\mathrm{H}_{1}$ is accepted. The next important study is the development of Quipper School media through a Facebook account on strengthening psychomotor competence in the field of Islamic education studies.
\end{abstract}

Keywords: Quipper school; facebook; effectiveness; learning; Islamic education.

How to Cite: Das, W., Halik, A., \& Herlin, B. (2020). The Effectiveness of Islamic Education Learning with Creative Worksheets through the Application of Quipper with Facebook Account. Al-Ta lim Journal, 27(2). doi:https://doi.org/10.15548/jt.v27i2.619

\section{INTRODUCTION}

Contemporary learning places more emphasis on the use of information and communication technology (ICT). Learning quality indicators point to the extent of the adaptation process and the basis of ICT as a learning medium (Mowrer \& Klein, 2000; Rohmawati, 2015; Sackney \& Mergel, 2007; Segrave \& Holt, 2003). On the other hand, it 
appears that students do not respond to learning that is conventional and has not yet converged the latest ICT in learning (Hanafie Das et al., 2018). Students have a high interest in new innovations, especially in ICT, so that urgent learning is designed by adjusting the interests of students (Setiawan \& Purnomo, 2016). Therefore, educators have demands on mastery of ICT learning so that they can carry out the task of educating and teaching professionally (Irina, 2016). The presence of ICT in education can help the learning process effectively, efficiently, and conducive (Angelaina \& Jimoyiannis, 2012; Anggereni \& Khairurradzikin, 2016; Pelgrum, 2001).

The trend of developing a contemporary learning system is the use of ICT in learning in each education unit (Biesta, 2016; Kompf, 2005; Maria \& Sediyono, 2017). School facilities and infrastructure standards emphasize the provision and use of ICTs as triggers and triggers for improving the quality of education and learning (Law No. 20 of 2003, Articles 35 and 40). The government provides assistance to ICT facilities to schools, both in the form of hardware and software. Assistance in the form of hardware in the form of procurement of computers and their devices and procurement of $\mathrm{Wi}-\mathrm{Fi}$ at school. Then assistance in the form of software that is making online learning application platforms, such as elearning, google classroom, quipper school, and so on (Cahyono, 2015; Idin \& Romadhoni, 2016; Wijanayu et al., 2018). The government's commitment to improving the quality of education and learning in schools is very high as evidenced by the significance of assistance to schools in the framework of catching up in various aspects.

Quipper school is popular learning software for students in SMKN 1 Sengkang, especially the Computer Network Engineering Department (TJK). Students are familiar with the application of quipper school learning so it is very urgent and relevant to be applied in every field of study (Tandirerung \& Hadi, 2014). On the other side, the PAI study field has not received a response from students, because of various problems, such as psychic students who do not want to be monotonous, Islamic teachings are popular in families and communities, learning strategies by educators have not matched the conditions of students, and so on. Various learning problems in the field, assessed the use of quipper school can be a solution for increasing student learning motivation in class (Agustina \& Cahyono, 2017; Saptani, 2016; Sulisworo et al., 2017; Virdhiyanto, 2013). Quipper school makes it easy for students to do their assignments online with laptop, notebook and android tools. Student assignments in Quipper school can be done at home and at school in a short time.

Quipper school is an application designed to facilitate the tasks of educators in learning and increase students' interest in learning Islamic education (Buntoro et al., 2018). SMKN 1 Sengkang can implement quipper school because it has adequate facilities especially in the TKJ Department. Educators and TKJ Department students understand the application of quipper school which is the main 'capital' applied to PAI learning. Completeness of the quipper school features in accessing learning needs, educators can control the learning progress of students, cognitive, affective, and psychomotor, through providing evaluations such as filling out Creative Student Worksheets (Dewi et al., 2019; Muskita \& Subali, 2020; Ransom \& Manning, 2013; Yulianti et al., 2020). Worksheets generally contain practice questions and review teaching materials for each topic (Zahro et al., 2017). The design of PAI-based PAI learning through Facebook accounts is very important to be developed to control the learning progress of students by giving creative worksheets. Thus, it aims to determine the significance differences by those who are taught using Quipper through a facebook account in assigning creative worksheets and those who are not taught using Quipper in the field of Islamic education studies. 


\section{METHODS}

This type of research is experiment. The experimental research used Quasi Nonequivalent control group design. The experimental group and the control group are intensively arranged so that both variables have the same or nearly the same characteristics, the experimental group is given a certain treatment or treatment while the control group is not given a certain treatment with consideration of the difficulty of controlling all variables that affect the variables to be studied (Nazir, 2005).

The population of this study was all students of class X Department of Computer Network Engineering (TKJ) SMK Negeri 1 Sengkang amounted to 70 . The total population was also used as a research sample. The sample was divided into two classes, namely the experimental class and the control class with a total of 35 students each class. The research instruments used were 1) Student Observation Sheet; 2) Student Learning Outcomes Test in the form of worksheets; 3) Questionnaire; 4) study documents; and 5) triangulation.

Quantitative data analysis with statistical techniques, namely descriptive statistical techniques and non-parametric statistical techniques inferential non test mann-whitney U-Test which is a test to determine the differences between two free groups with ordinal bound variable data scales or intervals / ratios not normally distributed and not homogeneous with using SPSS version 24.

\section{RESULTS AND DISCUSSIONS}

\section{Learning Effectiveness Results of Control Classes}

Data from observations of an Sengkang Vocational High School 1 (Hamran, 2018) educator on the effectiveness of class X TKJ Sengkang Vocational High School students in the control class during learning can be seen in the following table:

Table 1. Observation Results of the Effectiveness of Classroom Learning Control (Pretest)

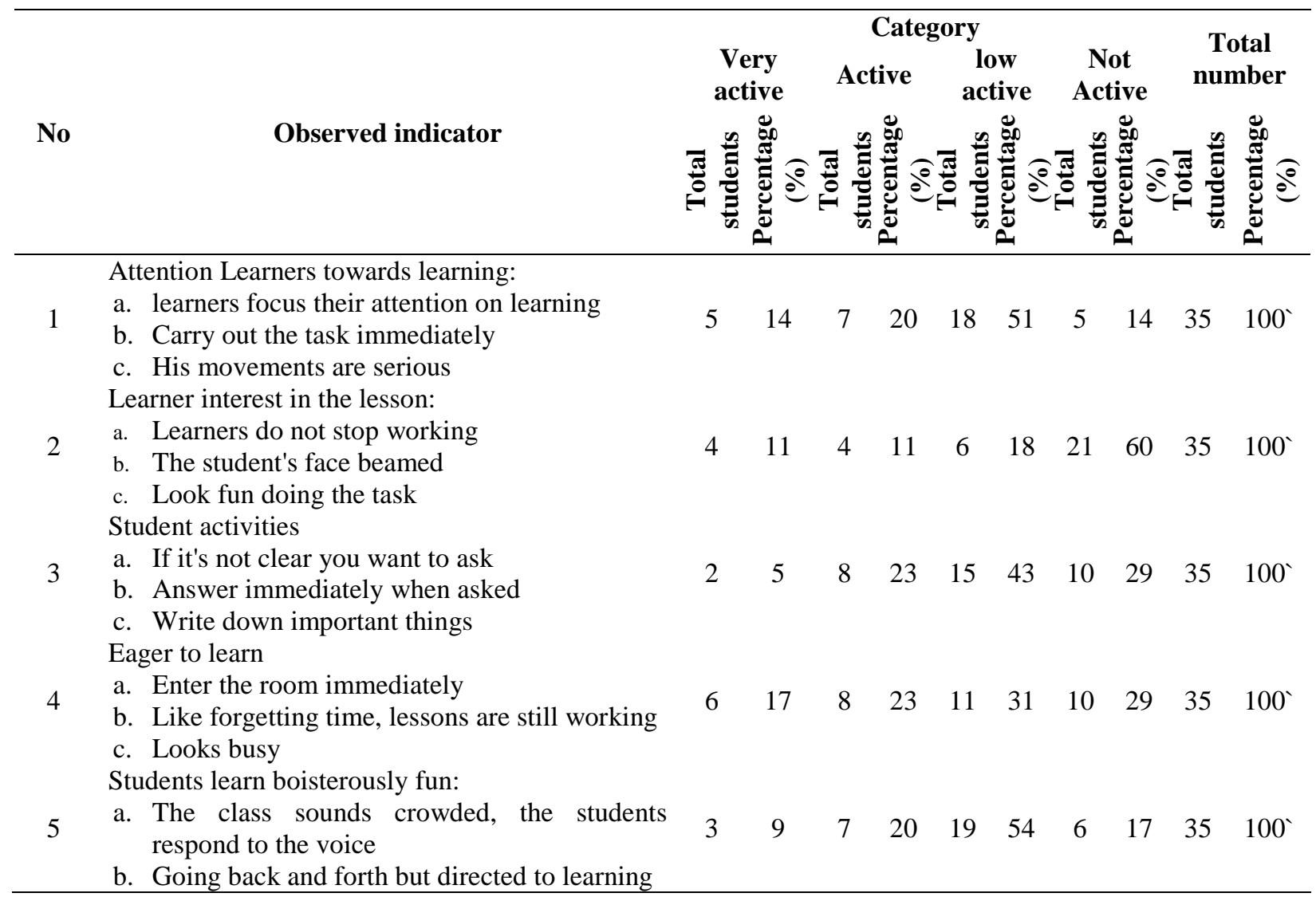




$\begin{aligned} & \text { c. Upon completion of the assignment, the } \\ & \text { learners appear happy }\end{aligned}$
Observed indicator

Based on the above, the results of observations of the learning effectiveness of students in the control class of Islamic Religious Education subjects at the time of the pretest, namely the attention of students towards learning categorized as less active as many as 18 students with a percentage of $51 \%$; Students' interest in inactive category is 21 students with a percentage of $60 \%$; Activities of students in learning activities categorized as less active as many as 15 students with a percentage of $43 \%$; The spirit of learning is categorized as less active as many as 11 students with a percentage of
$31 \%$, even the category of inactive as many as 10 students with a percentage of $29 \%$. Students learn with a fun atmosphere that is categorized as less active as many as 19 students with a percentage of $54 \%$; The state of orderly learning is categorized as less active as many as 16 students with a percentage of $46 \%$.Implementation of learning smoothly categorized as inactive as many as 20 students with a percentage of $58 \%$. Thus, PAI learning of students in the control class at the time of the pretest shows less active or ineffective.

Table 2. Observation Results of the Effectiveness of Classroom Learning Control (post test)

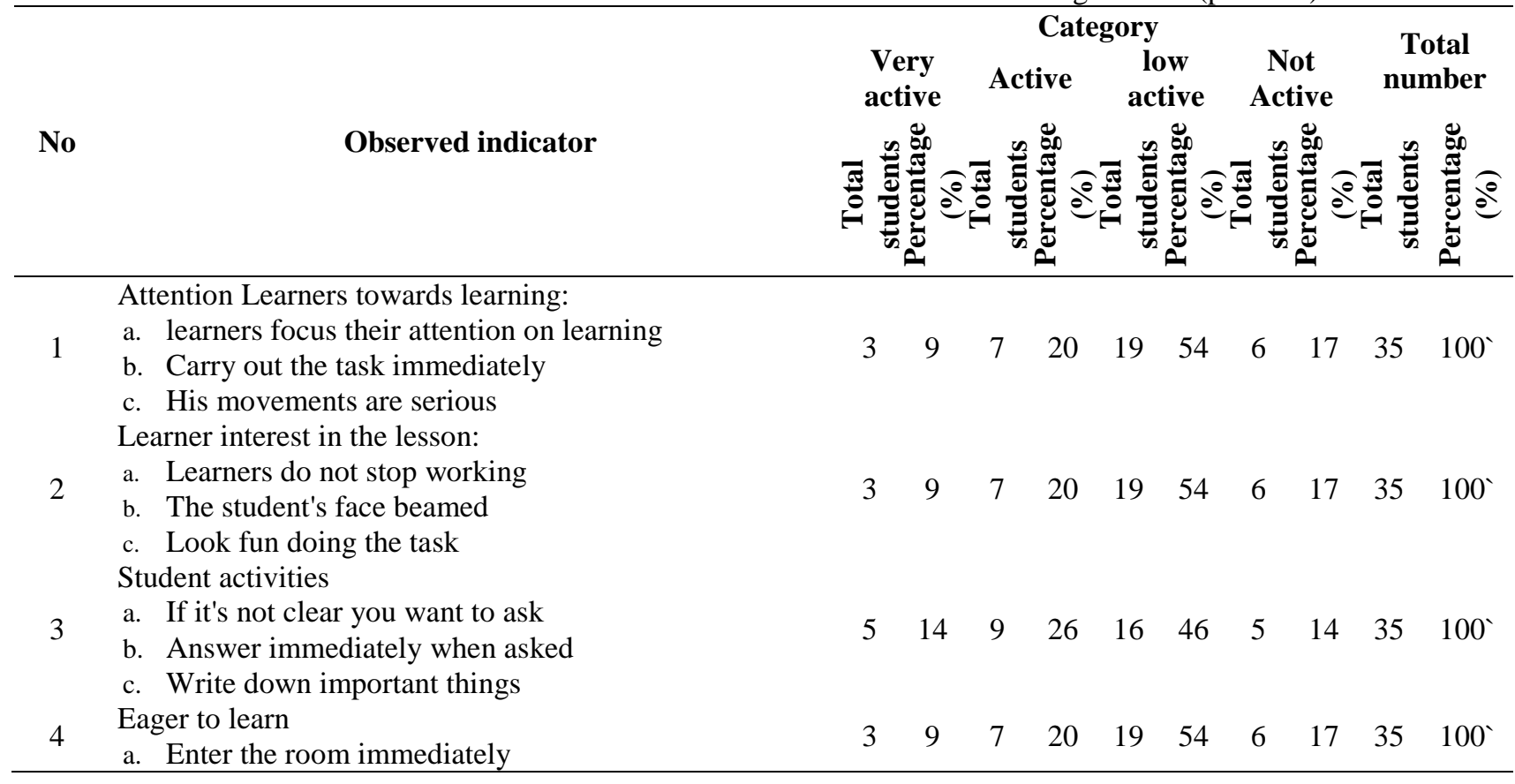


b. Like forgetting time, lessons are still working

c. Looks busy

\begin{tabular}{|c|c|c|c|c|c|c|c|c|c|c|c|}
\hline \multirow[b]{3}{*}{ No } & \multirow[b]{3}{*}{ Observed indicator } & \multicolumn{8}{|c|}{ Category } & \multirow{2}{*}{\multicolumn{2}{|c|}{$\begin{array}{c}\text { Total } \\
\text { number }\end{array}$}} \\
\hline & & $\begin{array}{l}\text { Ver } \\
\text { acti }\end{array}$ & & Activ & & & $\begin{array}{l}\text { w } \\
\text { ive }\end{array}$ & & $\begin{array}{l}\text { ot } \\
\text { tive }\end{array}$ & & \\
\hline & & 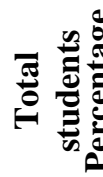 & 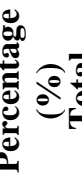 & 䒺 & 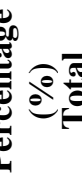 & 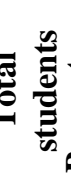 & बे & 恶 & 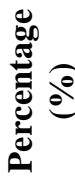 & 造 & 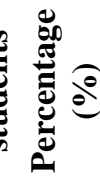 \\
\hline 5 & $\begin{array}{l}\text { Students learn boisterously fun: } \\
\text { a. The class sounds crowded, the students respond to } \\
\text { the voice } \\
\text { b. Going back and forth but directed to learning } \\
\text { c. Upon completion of the assignment, the learners } \\
\text { appear happy }\end{array}$ & 3 & 9 & 7 & 20 & 19 & 54 & 6 & 17 & 35 & $100^{-}$ \\
\hline 6 & $\begin{array}{l}\text { The state of learning is orderly } \\
\text { a. If you want to ask raise your hand } \\
\text { b. Each PD is absorbed in his duties } \\
\text { c. The group leader reprimands if there are students } \\
\text { who are negligent }\end{array}$ & 5 & 14 & 9 & 26 & 16 & 46 & 5 & 14 & 35 & $100^{\circ}$ \\
\hline 7 & $\begin{array}{l}\text { Implementation of learning smoothly } \\
\text { a. Cut each indicator according to the target time } \\
\text { b. There was no apparent stopping activity } \\
\text { c. The lesson finishes at the specified time }\end{array}$ & 4 & 11 & 4 & 11 & 7 & 20 & 20 & 58 & 35 & $100^{\circ}$ \\
\hline
\end{tabular}

Based on the table above, the results of observations of the learning effectiveness of students in the control class of Islamic Religious Education Subjects at the time of the post-test, namely the attention of students towards learning categorized as less active as many as 19 students with a percentage of 54\%; The interest of students in the lessons in the category of less active as many as 19 students with a percentage of 54\%; Activities of students in learning activities categorized as less active as many as 16 students with a percentage of $46 \%$; The spirit of learning is categorized as less active as many as 19 students with a percentage of $54 \%$; Students learn with a fun atmosphere that is categorized as less active as many as 19 students with a percentage of $54 \%$; The state of orderly learning is categorized as less active as many as 16 students with a percentage of $46 \%$.Implementation of learning smoothly categorized as inactive as many as 20 students with a percentage of $58 \%$. Then it can be concluded that the results of observations of the learning effectiveness of students in the control class have not reached the expected assessment standard.

\section{Learning Instrument Test Results}

Learning outcomes of students in Islamic Religious Education subjects, both in the pre-test and post-test in the control class, can be seen in the following table:

Table 3. Statistical Analysis of Student Learning Outcomes Test Instruments Control Classes

\begin{tabular}{lcc}
\hline \multicolumn{1}{c}{ Statistics } & Score & \\
& Pre-test & Post-test \\
\hline Average & 49 & 53 \\
The Lowest Score & 30 & 30 \\
The Highest Score & 60 & 70 \\
Minimal completeness criteria ( KKM) & 80 & 80 \\
\hline
\end{tabular}

Learning outcomes of the subjects above show far below KKM standards, so students are required to take remedial learning as a whole. The average value of student 
learning outcomes confirms that the learning of Islamic Education in the Department of Computer Engineering at SMK Negeri 1 Sengkang requires creativity that can trigger an increase in student motivation. PAI Subject
Educators are required to implement completeness-based learning based on the achievement of KKM, becoming an important argument for the application of quipper school learning media.

Table 4. Statistical Analysis Time/Minutes Learning Outcomes of the Test Instrument Students in the Control Class

\begin{tabular}{lcc}
\hline \multicolumn{1}{c}{ Statistics } & Pre-test & Score \\
& Post-test \\
\hline Average time obtained & 31 minutes & 24 minutes \\
Determined effective time & 15 minutes & 15 minutes \\
\hline
\end{tabular}

Based on the above, it appears that those who are taught in Islamic religious education do not use quipper School through a Facebook account in assigning Class $\mathrm{X}$ Student Computer Worksheets (LKS) in the State Vocational School 1 Sengkang to the control class, the results obtained have not yet reached the target. statistical analysis of the time / minute used in completing the test results of the learning outcomes students control class pre-test the average time required 31 minutes, the average test post 24 minutes, while the effective time determined for pre-test and post-test is 15 minutes. Then it can be concluded that the results of the test instructor learning were not achieved because the minimum completeness criteria and the effectiveness of time that had not been fulfilled for the subject matter of imitating the struggle of the Prophet Muhammad in Madinah on subjects of Islamic education class X semester at SMK Negeri 1 Sengkang.

\section{The Effectiveness of Experimental Class Learning Results}

Observation of learning outcomes of Islamic Religious Education Subjects for control class students during the learning process obtained by using an observation sheet (Hamran, S.Pd) in Class X Department of Computer Network Engineering (TKJ) SMK 1 Sengkang can be seen in the following table:

Table 5. Observation Results of the Effectiveness of Experimental Class Learning (Pretest)

\begin{tabular}{|c|c|c|c|c|c|c|c|c|c|c|c|}
\hline \multirow[b]{3}{*}{ No } & \multirow[b]{3}{*}{ Observed indicator } & \multicolumn{8}{|c|}{ Category } & \multirow{2}{*}{\multicolumn{2}{|c|}{$\begin{array}{c}\text { Total } \\
\text { number }\end{array}$}} \\
\hline & & \multicolumn{2}{|c|}{$\begin{array}{l}\text { Very } \\
\text { active }\end{array}$} & \multicolumn{2}{|c|}{ Active } & \multicolumn{2}{|c|}{$\begin{array}{c}\text { low } \\
\text { active }\end{array}$} & \multicolumn{2}{|c|}{$\begin{array}{c}\text { Not } \\
\text { Active }\end{array}$} & & \\
\hline & & 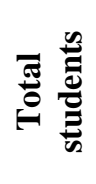 & 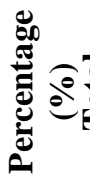 & 흉 & 尊 & 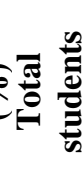 & 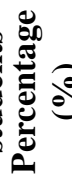 & $\frac{2}{2}$ & : & 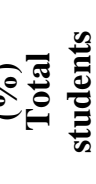 & 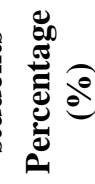 \\
\hline 1 & $\begin{array}{l}\text { Attention Learners towards learning: } \\
\text { a. learners focus their attention on learning } \\
\text { b. Carry out the task immediately } \\
\text { c. His movements are serious }\end{array}$ & 4 & 11 & 4 & 11 & 7 & 20 & 20 & 58 & 35 & $100^{\circ}$ \\
\hline 2 & $\begin{array}{l}\text { Learner interest in the lesson: } \\
\text { a. Learners do not stop working } \\
\text { b. The student's face beamed } \\
\text { c. Look fun doing the task }\end{array}$ & 2 & 6 & 8 & 23 & 15 & 43 & 10 & 29 & 35 & $100^{\circ}$ \\
\hline 3 & $\begin{array}{l}\text { Student activities } \\
\text { a. If it's not clear you want to ask } \\
\text { b. Answer immediately when asked } \\
\text { c. Write down important things }\end{array}$ & 5 & 14 & 9 & 26 & 16 & 46 & 5 & 14 & 35 & $100^{\circ}$ \\
\hline 4 & $\begin{array}{l}\text { Eager to learn } \\
\text { a. Enter the room immediately }\end{array}$ & 3 & 9 & 7 & 20 & 19 & 54 & 6 & 17 & 35 & $100^{\circ}$ \\
\hline
\end{tabular}




b. Like forgetting time, lessons are still
working
c. Looks busy

Based on the table above, the results of observations of the learning effectiveness of students in the experimental class of Islamic Religious Education subjects at the time of the pretest, namely the attention of students towards learning categorized as inactive as many as 20 students with a percentage of $58 \%$; The interest of students in the lessons in the category of less active as many as 15 students with a percentage of $43 \%$; Activities of students in learning activities categorized as less active as many as 16 students with a percentage of $46 \%$; The spirit of learning is categorized as less active as many as 19 students with a percentage of $54 \%$; Students learn with a fun atmosphere that is categorized as less active as many as 19 students with a percentage of 54\%; The state of orderly learning is categorized as less active as many as 16 students with a percentage of $46 \%$. The implementation of smooth learning is categorized as less active as many as 11 students with a percentage of $31 \%$ even the category of inactive as many as 10 students with a percentage of $29 \%$. Thus, PAI learning of students in the experimental class at the time of the pretest showed less active or ineffective. Furthermore, the effectiveness of learning in the experimental class at the time of the post tests, as in the following table:

Table 6. Observation Results of the Effectiveness of Experimental Class Learning (Post-Test)

\begin{tabular}{|c|c|c|c|c|c|c|c|c|c|c|c|c|}
\hline \multirow[b]{3}{*}{ No } & \multirow{3}{*}{\multicolumn{2}{|c|}{ Observed indicator }} & \multicolumn{8}{|c|}{ Category } & \multirow{2}{*}{\multicolumn{2}{|c|}{$\begin{array}{c}\text { Total } \\
\text { Number }\end{array}$}} \\
\hline & & & & & & tive & & $\begin{array}{l}\text { low } \\
\text { ctive }\end{array}$ & $\begin{array}{r}\mathrm{N} \\
\text { Act }\end{array}$ & $\begin{array}{l}\text { ot } \\
\text { tive }\end{array}$ & & \\
\hline & & & 吾 & & & S & & 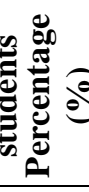 & م) & 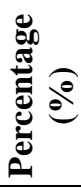 & 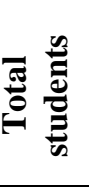 & 。 \\
\hline 1 & $\begin{array}{l}\text { Attention Learners towards learning: } \\
\text { a. Learners focus their attention }\end{array}$ & on & 33 & 94 & 1 & 3 & 1 & 3 & 0 & 0 & 35 & 100 \\
\hline
\end{tabular}




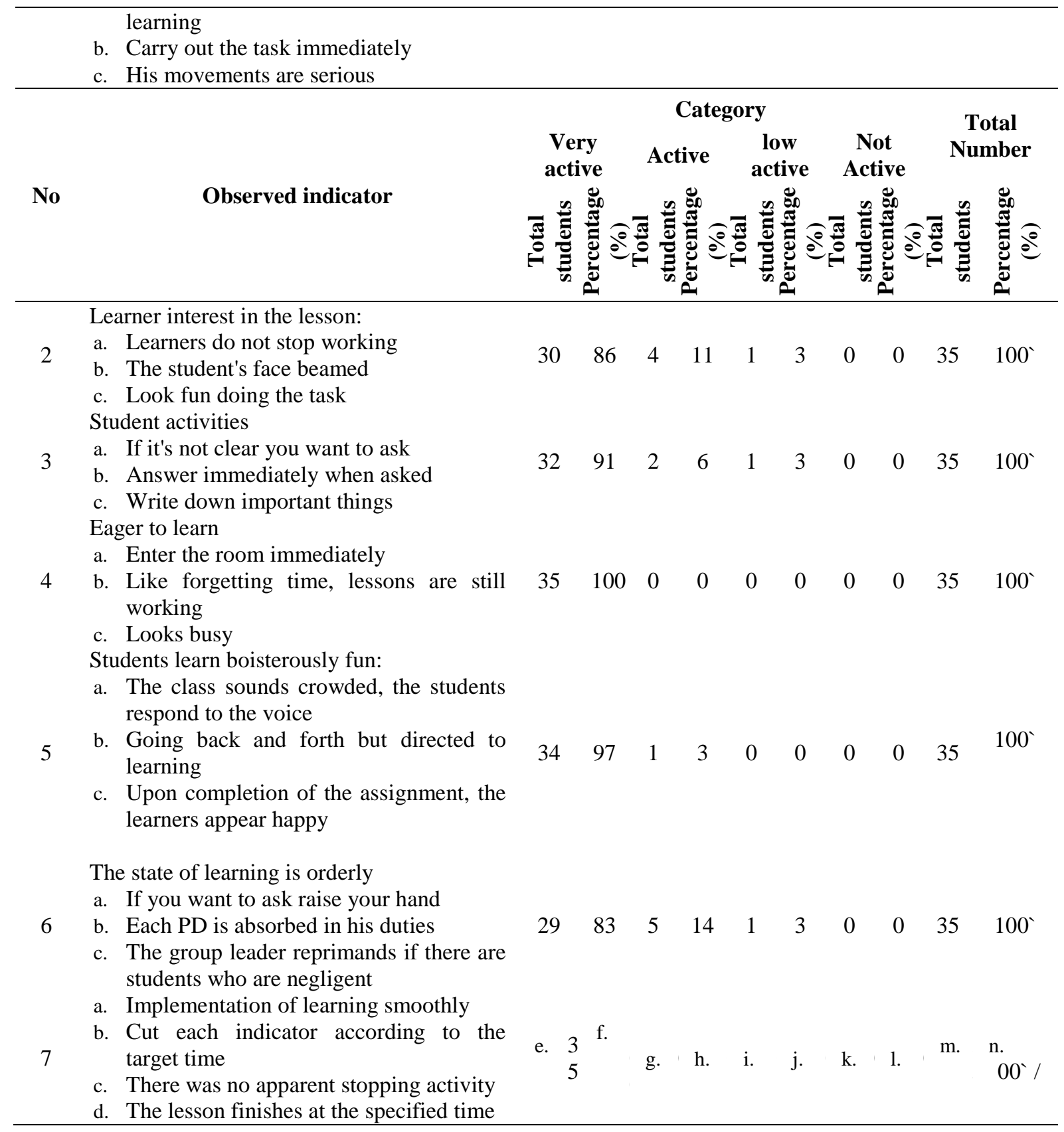

Based on the above table, the results of observations of the effectiveness of learning of students in the experimental class Islamic Education Subjects at the time of the post test, namely the attention of students towards learning categorized as very active as many as 33 students with a percentage of 94\%; The interest of students in the category of lessons is very active as many as 30 students with a percentage of $86 \%$; Activities of students in learning activities categorized as very active as many as 32 students with a percentage of $91 \%$; The spirit of learning is categorized very active as many as 35 students with a percentage of $100 \%$; Students learn with a fun atmosphere that is categorized as very active as many as 34 students with a percentage of $97 \%$; The state of orderly learning is categorized as very active as many as 29 students with a percentage of $83 \%$. The implementation of learning smoothly is categorized as very active as many as 35 students with a percentage of $100 \%$. So it can be concluded that the results of observations of the learning effectiveness of students in the experimental class at the time of the post test achieved 
maximum results, namely the very active category.

\section{Learning Instrument Test Results}

Learning outcomes of students in Islamic Religious Education subjects, both in the pretest and post test in the experimental class, can be seen in the following table:

Table 7. Statistical Analysis of Student Learning Outcomes Test Instruments Experimental Classes

\begin{tabular}{|c|c|c|c|}
\hline Statistics & Pre-Test & $\begin{array}{c}\text { Score } \\
\text { Experiment } \\
\text { (Quipper School) }\end{array}$ & Post Test \\
\hline Average & 42 & 98 & 98 \\
\hline Lowest Value & 30 & 90 & 90 \\
\hline The highest score & 60 & 100 & 100 \\
\hline Maximum Time/Minute & 80 & 80 & 80 \\
\hline
\end{tabular}

The learning outcomes of the Subjects above indicate that the KKM standard is very much achieved, so students do not participate in remedial learning. The average value of student learning outcomes confirms that PAI learning in the TKJ Department of SMK Negeri 1 Sengkang is important to be developed because it can trigger an increase in students' learning motivation. PAI Subject
Educators are required to implement completeness-based learning based on the achievement of KKM, becoming an important argument to be applied in quipper schoolbased learning media. Furthermore, the time analysis used in the Experiment class in working on problems can be seen in the following table:

Table 8. Statistical Analysis Time/Minutes Learning Results Test Instruments Experiment Classes

\begin{tabular}{lccc}
\hline \multicolumn{1}{c}{ Statistics } & Pre-test & $\begin{array}{c}\text { Score } \\
\text { Experiment } \\
\text { (Quipper School) }\end{array}$ & Post-test \\
\hline Average time obtained & 37 minute & 8 minute & 8 minute \\
Determined effective time & 15 minute & 15 minute & 15 minute \\
\hline
\end{tabular}

Based on the table above, it appears that PAI learning does not use Quipper School through a Facebook account in assigning class $\mathrm{X}$ LKS assignments at TKJ SMKN 1 Sengkang to the control class obtained an average of pre-test 42, treatment with Quipper School 98 and post-test 98 , the lowest pretest score 30 , treatment 90 , posttest 90 , highest score pretest 60 , treatment 100 , posttest 100, minimum completeness criteria (KKM) pretest 80 , treatment 80 , posttest 80.Whereas in table 8 , the statistical analysis of time / minutes used in completing the test results of the learning outcomes of the experimental class students pre-test the average time needed is an average of 37 minutes, 8 minutes treatment, 8 minutes test post, while the effective time is determined for the pretest, treatment and posttest is 15 minutes. Then it can be concluded that the results of the test instructor learning were achieved because of the KKM fulfillment and the effectiveness of the time that had been set for the subject matter to emulate the struggle of the Prophet Muhammad in Medina on the subject of Islamic religious education class X semester at SMK Negeri 1 Sengkang.

\section{Interests of Students Learning PAI Through Quipper School}

After being given a learning treatment using Quipper School media on experimental class students, questionnaires were then distributed to find out the extent of students' interest in using Quipper School media in doing their assignments. The interest questionnaire using the Likert scale strongly 
agrees, agrees, disagrees and disagrees. The questionnaire was distributed to 35 experimental class students, who were then recapitulated in the following table:

Table 9. Recapitulation of Quipper School Learning Interest questionnaire results for the Experiment class

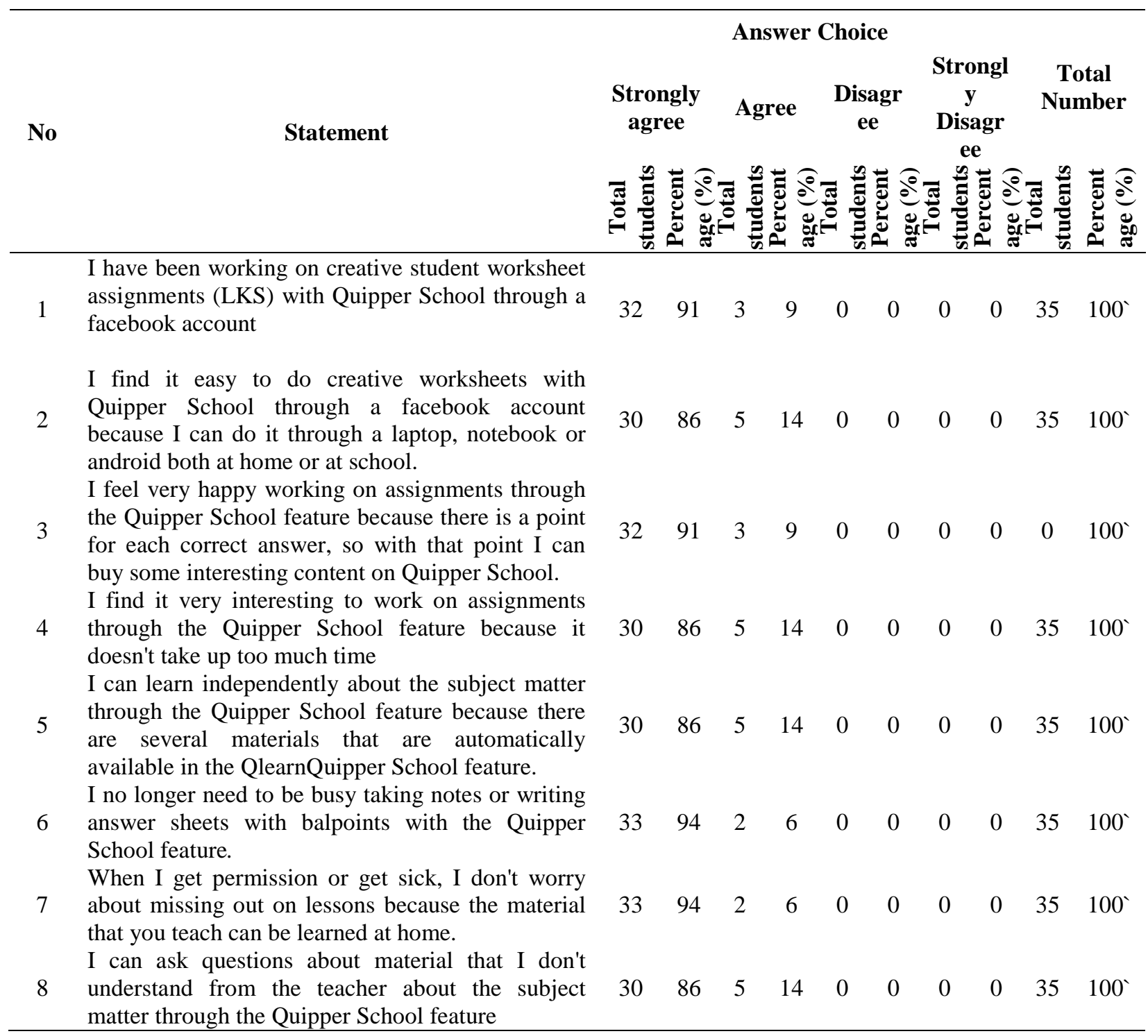

Based on the table above, the results of the student questionnaire that stated I had done the work of Creative Worksheets with a quipper school through a Facebook account that responded with answers strongly agreed as many as 32 respondents or $91 \%$; A statement that I find it easy to work on Creative Worksheets with Quipper School through a Facebook account because I can do it via laptop, notebook or android, both at home or at school. with answers strongly agree 30 respondents or $86.7 \%$; Statement that I feel very happy doing the assignment through the Quipper School feature because there is a point for each correct answer, so with that point I can buy some interesting content at Quipper School with

the answer strongly agreeing to 32 respondents or 91\%; Statement that I find it very interesting to do the work through the Quipper School feature because it does not take up much time, with answers strongly agree 30 respondents or $91 \%$;Statement that I can learn independently about the subject matter through the Quipper School feature because there are several materials that are 
automatically available in the learn Quipper School feature with answers that strongly agree, 30 respondents or $86 \%$; Statement that I no longer need to be busy taking notes or writing answer sheets with ballpoints with the Quipper School feature with answers that agree strongly, that is 33 respondents or $94 \%$; Statement that if I am licensed or sick, I am not worried about missing out on lessons because the material that you teach can be learned at home with answers that are very amenable, i.e. 33 respondents or $94 \%$; Statement that I can ask questions about material that I do not understand the teacher about the subject matter through the Quipper
School feature with answers that strongly agree that is 30 respondents or $86 \%$. Thus, students consider that the use of the quipper school feature through a Facebook account is very good and strongly agrees if it is implemented on an ongoing basis.

\section{Mann-Whitney U Test results}

For this difference test the SPSS Version 24 data test was used using the mann whitney test or $U$ test for the cognitive learning outcomes of students in the post test control class and experimental class and the following data were obtained:

Table 10. U SPSS Test Results Version 24. Post Test Control Class and Experiment Class NPar Tests Mann-Whitney Test

\begin{tabular}{|c|c|c|c|c|}
\hline \multicolumn{5}{|c|}{ Ranks } \\
\hline & & & Mean & Sum Of \\
\hline & Class & $\mathrm{N}$ & Rank & Ranks \\
\hline Quipper School Learning & Class Control & 35 & 18,00 & 630,00 \\
\hline Results & Class Experiments & 35 & 53,00 & 1855,00 \\
\hline & Total & 70 & & \\
\hline
\end{tabular}

\begin{tabular}{|c|c|}
\hline \multicolumn{2}{|c|}{ Test Statistics $^{\text {a }}$} \\
\hline & \\
\hline Mann-Whitney U &, 000 \\
\hline Wilcoxon W & 630,000 \\
\hline $\mathrm{Z}$ & $-7,496$ \\
\hline Asymp. Sig. (2-tailed) &, 000 \\
\hline a. Grouping Variable: KELAS & \\
\hline
\end{tabular}

Source: SPSS output version 24.

The basis for Mann Whitney's decision making, if the Asymp.Sig value <0.05, then the hypothesis H0 is rejected $\mathrm{H} 1$ is accepted. If the Asymp.Sig value> 0.05, then the hypothesis $\mathrm{H} 0$ is rejected $\mathrm{H} 1$ is rejected. Based on the "Test Statistics" output in the mann-whitney test the Asymp.Sig value is known. (2- tailed) of 0,000 is smaller than <probability value of 0.05 , then the hypothesis $\mathrm{H} 0$ is rejected $\mathrm{H} 1$ is accepted. then it can be concluded that the hypothesis $\mathrm{HO}$ is rejected $\mathrm{H} 1$ which means there are different learning outcomes using and not Quipper School through a facebook account in assigning creative worksheets. Because there are significant differences, it can be said that the use of Quipper School through a facebook account in the assignment of creative worksheets increases the learning effectiveness of PAI Subjects in class X students of TKJ Department, SMK Negeri 1 Sengkang.

Every important lesson is planned comprehensively so that it can run effectively and efficiently. The aspects planned and prepared before the learning process activities are learning tools. Learning devices are a set of learning resources that enable students and educators to carry out learning activities. Appropriate learning tools such as onlinebased media, can motivate students more optimally in participating in learning (Anggraini, 2016). Learning devices can be effective if the educator is able to communicate conductively through 
appropriate media with students in the classroom (Tuhuteru, 2019). Learning becomes quality if educators have competence, complete learning tools, and are supported by ICT facilities in the education unit.

This study used 70 respondents, the control class consisted of 35 samples and 35 experimental samples were unpaired. The control class was not given learning treatment using Quipper School media; the experimental class was given learning treatment using Quipper School media. This hypothesis test states that there is a significant difference in using and not using Quipper School through a Facebook account in assigning creative worksheets to improve the effectiveness of learning the subject of PAI Class X TKJ Department at SMK Negeri 1 Sengkang. The presence of Quipper School is expected to reduce the negative impact of social media such as the use of Facebook.

The use of Quipper School through Facebook accounts in giving LKS assignments to improve the learning effectiveness of PAI Subject students. Creative LKS can be created by educators in the use of Quipper school through this Facebook account. Creative Worksheets if they meet the active requirements, construction requirements, and technical requirements (Putra, 2016). Creative LKS is more effective if it is adapted to quipper school learning media. Quipper School is a free online platform for educators with its features (Quipper link) and students (Quipper Learn). This platform helps educators manage classes online and see students' development directly. Quipper Learn can make it easier for students to do assignments online with laptop, notebook and android tools. Students' assignments in Quipper Learn can be done at home and at school in a short time (Tandirerung, 2014).

The application of quipper school can trigger an increase in learning effectiveness as well as with students' learning interest. Research shows that conventional PAI learning causes the low learning interest of students which has implications for failure and incompleteness based on KKM (Das, 2018). The use of e-learning quipper school as a place to do the tasks given by educators, then students access the subject matter, if there are difficulties students can send through the message menu about material that is not yet understood (Saraswati, 2018). Quipper school-based learning media experiments indicate the importance of students learning online. Quipper schoolbased learning is very appropriate for grade $\mathrm{X}$ students of the TKJ Vocational School 1 Sengkang. PAI learning is considered by students as learning that is saturating, boring, and unfocused, so it is very urgent and relevant to the application of quipper school. The presence of quipper schools becomes a more effective, efficient, flexible, distributive, scientific, rational, and humanist alternative to PAI learning.

\section{CONCLUSION AND RECOMMENDATION}

The effectiveness of students' learning does not use Quipper School through a facebook account in assigning Creative Worksheets to class $X$ students of the TKJ Department in SMK Negeri 1 Sengkang not meeting the minimum completeness criteria (KKM) set by the SMK Negeri 1 Sengkang in educational learning activities The second half of Islamic religion subject matter emulated the struggle of the Prophet Muhammad in Medina.

Learning effectiveness of students using Quipper School through a facebook account in assigning creative worksheets to improve the effectiveness of PAI learning in class X students of TKJ at SMK 1 Sengkang meet the minimum completeness criteria (KKM) set by SMK Negeri 1 Sengkang in learning activities PAI Semester II's subject matter exemplifies the struggle of the Prophet Muhammad in Medina.

Significant differences in the effectiveness of learning that uses and does not use quipper school through a Facebook 
account in assigning creative worksheets to improve the effectiveness of learning in the field of PAI in class X Department of TKJdi SMK Negeri 1 Sengkang is evidenced by the existence of different learning outcomes using test instruments, observation during the process of learning activities, student questionnaire interests in learning Quipper School. Based on the "Test Statistics" output in the mann-whitney test the Asymp.Sig value is known. (2- tailed) of 0,000 is smaller than sprobability value of 0.05 , then the hypothesis $\mathrm{H}_{0}$ is rejected $\mathrm{H}_{1}$ is accepted. Significant differences in the effectiveness of learning that uses and does not use quipper school through a Facebook account in assigning creative worksheets to improve the effectiveness of learning in the field of PAI in class X Department of TKJ at SMKN 1 Sengkang is evidenced by the existence of different learning outcomes using test instruments, observation during the process of learning activities, student questionnaire interests in learning Quipper School. Based on the "Test Statistics" output in the mannwhitney test the Asymp.Sig value is known. (2- tailed) of 0,000 is smaller than <probability value of 0.05 , then the hypothesis $\mathrm{H}_{0}$ is rejected $\mathrm{H}_{1}$ is accepted. The next important study is the development of Quipper School media through a Facebook account on strengthening psychomotor competence in the field of PAI studies.

\section{REFERENCES}

Agustina, E., \& Cahyono, B. Y. (2017). Perceptions of Indonesian Teachers and Students on the Use of Quipper School as an Online Platform for Extended EFL Learning. Journal of Language Teaching and Research, 8(4), 794-800.

Alfurqan, A., Tamrin, M., Trinova, Z., \& Zuhdiyah, Z. (2019). The Problematics of Islamic Religious Education Teacher In Using of Instructional Media at SD Negeri 06 Pancung Soal Pesisir Selatan. Al-Ta Lim Journal, 26(1), 56-64.
Angelaina, S., \& Jimoyiannis, A. (2012). Analysing students' engagement and learning presence in an educational blog community. Educational Media International, 49(3), 183-200.

Anggereni, S., \& Khairurradzikin, K. (2016). Efektivitas pembelajaran menggunakan media pembelajaran macromedia flash dalam meningkatkan pemahaman konsep fisika materi hukum Newton. Jurnal Biotek, 4(2), 333-350.

Astuti, A. P. (2016). Pengembangan Instrumen Penilaian Kompetensi Membaca pada Mata Pelajaran Bahasa Indonesia Kelas VII Berbasis Quipper School. JINoP (Jurnal Inovasi Pembelajaran), 2(2), 334-350.

Biesta, G. (2016). ICT and education beyond learning. In Digital expectations and experiences in education (pp. 29-43). Springer.

Buntoro, G. A., Ariyadi, D., \& Astuti, I. P. (2018). Pemanfaatan e-learning quipper school oleh guru dan siswa untuk optimalisasi pembelajaran di MAN 1 Ponorogo. Jurnal Pengabdian Kepada Masyarakat (Indonesian Journal of Community Engagement), 1(2), 157-167.

Cahyono, Y. D. (2015). E-Learning (Edmodo) Sebagai Media Pembelajaran Sejarah. Jurnal Penelitian, 18(2).

Choo, S. S., Rotgans, J. I., Yew, E. H., \& Schmidt, H. G. (2011). Effect of worksheet scaffolds on student learning in problem-based learning. Advances in Health Sciences Education, 16(4), 517.

Dewi, L. S., Nyeneng, I. D. P., \& Suana, W. (2019). Development of Student Worksheets on Heat Material Based on Guided Inquiry to Increase Creative Thinking Skills. Kasuari: Physics Education Journal (KPEJ), 2(2), 110-120. 
Febriani, S., Sudomo, J., \& Setianingsih, W. (2017). Development of Student Worksheet Based on Problem Based Learning Approach to Increase 7th Grade Student's Creative Thinking Skills. Journal of Science Education Research, 1(1).

Gie, T. L. (2002). Cara belajar yang efisien. Jilid I Edisi Ke, 5.

Halik, A., \& Juliadi, J. (2019). PAI Learning Design Based on 2013 Curriculum and Implications for Learning Motivation of Students in State Senior High School 10 of Enrekang. International Conference on Natural and Social Sciences (ICONSS) Proceeding Series, 420-428.

Halik, A., Zulfianah, Z., \& Naim, M. (2018). Strategies of Islamic Education Teachers to Increase Students' Interest In Learning and Practicing in State Junior High School Lanrisang (SMPN) 1 Lanrisang, Pinrang. MADANIA: Jurnal Kajian Keislaman, 22(2), 253-264.

Hanafie Das, S. W., Halik, A., Zulfianah, Z., \& Naim, M. (2018). Strategies of Islamic Education Teachers to Increase Students' Interest in Learning and Practicing in State Junior High School (SMPN) 1 Lanrisang, Pinrang. MADANIA, 22(2), 253-264.

Hurriyati, D., \& Arisandy, D. (2018). Pengaruh Penggunaan Media Belajar Quipper School Terhadap Minat Belajar Matematika Pada Siswa. Jurnal Psikogenesis, 6(2), 197-204.

Idin, A., \& Romadhoni, M. S. Z. (2016). Quipper School: How Do Teachers Bring IT in the Classroom? International Conference on Education and Language (ICEL), 118.

Irina, F. (2016). Dasar-dasar Ilmu pendidikan. Yogyakarta: Parama Ilmu.
Islami, A. V. (2020). Pembelajaran Fisika Berbantuan Quipper School Sebagai Media Pembelajaran. EXPLORE, 10(1).

Juwita, R., Utami, A. P., \& Wijayanti, P. S. (2019). Pengembangan lks berbasis pendekatan open-ended untuk meningkatkan kemampuan berpikir kreatif matematis siswa. Prima: Jurnal Pendidikan Matematika, 3(1), 35-43.

Karmila, N., \& Anggereni, S. (2017). Pengaruh penggunaan media pembelajaran quipper school terhadap minat belajar fisika siswa. Jurnal Pendidikan Fisika, 5(2), 120-127.

Kisworo, M. W. (2016). Revolusi Mengajar. Pembelajaran Aktif, Kreatif, Efektif, Menyenangkan (Pakem). Bandung: Asik Generation.

Kompf, M. (2005). Information and Communications Technology (ICT) and the seduction of knowledge, teaching, and learning: What lies ahead for education. Curriculum Inquiry, 35(2), 213-234.

Maria, E., \& Sediyono, E. (2017). Pengembangan model manajemen pembelajaran berbasis tik di sekolah dasar. Kelola: Jurnal Manajemen Pendidikan, 4(1), 59-71.

Mowrer, R. R., \& Klein, S. B. (2000). Handbook of contemporary learning theories. Psychology Press.

Muskita, M., \& Subali, B. (2020). Effects of Worksheets Base the Levels of Inquiry in Improving Critical and Creative Thinking. International Journal of Instruction, 13(2), 519-532.

Nazir, M. (2005). Metode Penelitian, cetakan keenam. Jakarta: Penerbit Ghalia Indonesia.

Pelgrum, W. J. (2001). Obstacles to the integration of ICT in education: 
Results from a worldwide educational assessment. Computers \& Education, 37(2), 163-178.

Putra, K. K. W., Wuisan, P., \& Listiani, T. (2016). Penggunaan Lembar Kerja Siswa (LKS) untuk Menigkatkan Hasil Belajar Kognitif Materi Bangun Ruang Sisi Lengkung pada Peserta Didik Kelas IX-B SMP XYZ Sentani Papua [Using Student Worksheets to Increase Cognitive Achievement of Curve Sides of Three Dimensional Space Figures of Grade IX-B Students at XYZ Junior High School in Sentani, Papua]. Polyglot: Jurnal Ilmiah, 12(2), 42-59.

Rahayu, E., \& Imran, A. (2017). Pengembangan lembar kerja siswa (lks) berorientasi pembelajaran inkuiri untuk meningkatkan keterampilan berpikir kreatif siswa. Jurnal Ilmiah Mandala Education, 3(1), 403-410.

Ransom, M., \& Manning, M. (2013). Teaching strategies: Worksheets, worksheets, worksheets. Childhood Education, 89(3), 188-190.

Rohmawati, A. (2015). Efektivitas Pembelajaran. Jurnal Pendidikan Usia Dini, 9(1), 15-32.

Sackney, L., \& Mergel, B. (2007). Contemporary learning theories, instructional design and leadership. In Intelligent leadership (pp. 67-98). Springer.

Saptani, D. A. (2016). Teachers' Perception towards the Use of Quipper School in Teaching English. Ninth International Conference on Applied Linguistics (CONAPLIN 9).

Segrave, S., \& Holt, D. (2003). Contemporary learning environments: Designing elearning for education in the professions. Distance Education, 24(1), 7-24.
Setiawan, B., \& Purnomo, E. (2016). Pelatihan media pembelajaran multimedia dengan powerpoint dan wondershare untuk pengembangan soft skills siswabagi guru SD \&TK1. Warta LPM, 19(1), 64-73.

Sulisworo, D. (n.d.). Using (quipper school APP.

Sulisworo, D., Sulistyo, E. N., \& Akhsan, R. N. (2017). The Motivation Impact of Open Educational Resources Utilization on Physics Learning Using Quipper School App. Turkish Online Journal of Distance Education, 18(4), 120-128.

Surahmadi, B. (2016). Pengaruh Media Pembelajaran Virtual Berbasis Quipper School Untuk Meningkatkan Motivasi Belajar dan Hasil belajar Peserta didik Kelas VIII SMP N 1 Temanggung. Unnes Science Education Journal, 5(1).

Tandirerung, V. A., \& Hadi, S. (2014). Implementasi e-learning program keahlian TKJ di SMK DIY pasca pembubaran RSBI. Jurnal Pendidikan Vokasi, 4(1).

Töman, U., Akdeniz, A. R., Odabasi Çimer, S., \& Gürbüz, F. (2013). Extended Worksheet Developed According to 5E Model Based on Constructivist Learning Approach. Online Submission, 4(4), 173-183.

Trisnaningsih, S., Suyanto, S., \& Rahayu, T. (2016). Pengembangan Learning Management System Quipper School pada Pembelajaran Materi Sistem Pertahanan Tubuh untuk Meningkatkan Motivasi dan Hasil Belajar Siswa Kelas XI di SMA Negeri 3 Yogyakarta. Jurnal Pendidikan Biologi, 5(6), 28-36.

Virdhiyanto, A. (2013). Pengembangan media pembelajaran interaktif pada standar kompetensi menerapkan dasar-dasar teknik digital. 
Wijanayu, A., Hardyanto, W., \& Isnaeni, W. (2018). Blended Learning Method Based on Quipper School to Improve Concepts Understanding and Independence Learning. Journal of Primary Education, 7(1), 88-95.

Wijayanti, R. R. (2016). Peningkatan Prestasi Belajar Siswa dengan BAntuan Penggunaan Media Quipper School. APOTEMA: Jurnal Program Studi Pendidikan Matematika, 2(1), 96-104.

Wisdiarman, W., \& Hafiz, A. (2017). Need analysis of scientific-based approach worksheet by using discovery learning model for seni budaya at junior high school. Komposisi: Jurnal Pendidikan Bahasa, Sastra, Dan Seni, 18(1), 8089.
Yulianti, D., Rusilowati, A., \& Nugroho, S. E. (2020). Student worksheets based on Science, Technology, Engineering and Mathematics (STEM) to facilitate the development of critical and creative thinking skills. Journal of Physics: Conference Series, 1567(2), 022068.

Zahro, U. L., Serevina, V., \& Astra, M. (2017). Pengembangan Lembar Kerja Siswa (LKS) Fisika dengan Menggunakan Strategi Relating, Experiencing, Applying, Cooperating, Transferring (React) Berbasis Karakter pada Pokok Bahasan Hukum Newton. WaPFi (Wahana Pendidikan Fisika), 2(1). 